AL-HIKMAH RESEARCH

\& PUBLICATION CENTER
Al-RashadJournalof Islamic Finance

Vol. 1, No. 3, June 2021

E-ISSN: $2637-0581$

DOI:10.46722/ajif.1.2.21a

\title{
Types of waqf in Oman
}

\author{
Said Rashid Said Al-Salmani ${ }^{1}$ \\ Graduate Research, IIUM IBF. (alsalmani22@gmail.com). \\ Ibrahim Nuhu Tahir ${ }^{2}$
}

Associate Professor at Department of Economics, International Islamic University Malaysia, Jalan Gombak, 53100, Kuala Lumpur, Malaysia. (Email: ibrahimnuhu@iium.edu.my).

\begin{abstract}
The Omani Waqf institution is one of the oldest waqf institutions in the Islamic world. This is because Omanis voluntarily accepted Islam, individually and collectively early in the sixth year of the Hijrah. Some researchers believe that the first waqf in Oman was established by the Companion Mazen Bin Ghadouba AlTai's. Since then, the waqf institution has played a prominent rule in Omani society. This article reveals the literatures of Omani waqf and discusses a brief historical development of the waqf institution in Oman followed by how it differs from other waqf institutions in the Islamic world. The main question of this study is; what are the types of waqf in Oman? To answer this question; content analysis as a research method is used. The study has three main objectives. The author found 60 types that are used and repeated in most waqf deeds. Waqf for children dominated the Awqaf of Omanis in the Sultanate of Zanzibar during the days of Omani rule. This was unlike the endowments in the mainland Oman. Waqf to Mosques is the most common type of endowment in Oman.
\end{abstract}

Keywords: waqf, Oman, Zanzibar, deed, Mosques.

\footnotetext{
${ }^{1}$ Graduate Research, IIUM IBF. (alsalmani22@gmail.com).

${ }^{2}$ Associate Professor at Department of Economics, International Islamic University Malaysia, Jalan Gombak, 53100, Kuala Lumpur, Malaysia. (Email: ibrahimnuhu@iium.edu.my).
} 
2 Types of waqf in Oman

\section{INTRODUCTION}

Waqf is a pious foundation that has provided all essential services throughout the Islamic civilization at no cost especially for poor people. Historically, waqf used to serve many ends, including mosques and religious schools but also non-religious services, such as fountains, inns for merchants and soup kitchens (Kuran, 2013, p396; Mohsin, 2010, p57; Çizakca, 1998, p45). Therefore, waqf properties are considered a potential main engine in supporting religious and social services as it used to be once upon a time in past Islamic civilization. Endowment -waqf- has played a vital role from the Prophetic Age until now. While from the middle of the last century endowment -waqf-is gaining more concern worldwide and has become one of the most developed fields of research in Islamic economics.

Despite these overwhelming achievements, waqf founders' stipulations have the force of law to be executed in accordance with the founder's instructions (Al-Zarqā, 1989, p155). Originally, endowers' stipulations held this strength because he/she stipulates conditions while establishing waqf to ensure proper performance. The most important point in any waqf deed is when the founder determines the purpose of that waqf and his or her intention behind that. Almost all waqf's founders stipulate in the waqf deed the purpose of their waqf. Consequently, Allah enforces the community to respect founders' stipulations in so long as they are not contrary to the Islamic law. This stipulation is a human effort intended by the endower to maximise the Earthly and the Heavenly worlds' benefits of the endowment. Therefore; types of waqf vary according to the place, time and different needs of the people. Moreover, along with the differences in the endower's knowledge of waqf provisions and other matters that may cause variations in waqf founders' stipulations and perhaps affect the status of the waqf.

However, variations in waqf support the interest of waqf and maximising its desired economic role. The waqf and its specific purposes set by the endowers contribute to the movement and development of capital, and the provision of a continuous income that meets the needs of beneficiaries in the present and future. Waqf in many economic studies conducted by Muslim and non-Muslim scholars has demonstrated its im- 
portance in activating the economic cycle, achieving growth, and addressing economic problems, in addition to the multiple social benefits ${ }^{3}$.

This research attempts to explore the objectives of Omani waqf and what puroses would be sverved.

\section{LITERATURE REVIEW}

The history of waqf in Oman is traced back to Mazin bin Gadobah ${ }^{4}(25$ A.H) the companion of the Prophet (苟). When he accepted Islam in the sixth year after hijrah (A.H) and returned to Oman. He built his Mosque which is considered the first Mosque and first waqf in Oman (AlBațashy, 2004, 1/25). Although waqf has been practiced by Omanis since their conversion to Islam, unfortunately the literature in this honourable foundation is of an inconsiderable portion. However; the earliest modern article to evaluate waqf in Oman was the 'Omani experience in managing waqf' which was compiled by Said Al-Aghbry ${ }^{(1993)}$. The researcher has served to highlight the problems of administration in the Ministry of Endowment and Religious Affairs in the Sultanate. Preliminary work on Omani waqf was conducted by Musā Al-Busa'̄̄d $\bar{\imath}^{(2002)}$. His Book about the beneficial ownership of waqf, and who represents this type of ownership in Oman. He further went on to recount some of the waqf history in Oman and the situation of waqf in this era. Salim Al$J a h a \bar{f} i{ }^{(2004)}$ sought to explain the civilizational and socio-economic im-

\footnotetext{
${ }^{3}$ For more details see these article: (Kuran, 2001; Omercic, 2016; Çizakca, 1998; Mușabh, 2013).

${ }^{4}$ Mazin Bin Ghadouba was the first Omani to become Muslim in the sixth year of A.H. He was born in Wilaytah (town) Samail Ad-Dakhiliyah Region of the Sultanate of Oman. The story of his Islam is famous in Omani history and books of Biography of the Prophet (السيرة النبوية). Before he became Muslim, he had own idol, which was called 'Bajer', as all Arab in that era of Jahiliyyahy. Then, he realized that the fetish cannot do anything, therefore, he broke the fetish and started searching for new religion until he heard about the prophet Muhammad (BPUH). He traveled to Madinah and converted to Islam after he met the Prophet (BPUH) in the sixth year of A.H. He narrated few Hadiths and some of his descents became traditionist. He was martyred in Azerbaijan in 25 A.H (Al-Asqalani, 1995, 5/520; Al-Bațashy, 2004,1/25; Ibn Al-Athir, 1994, 5/4)
} 
pact of $A w q \bar{a} f$ in the regime of Sultan Qaboos (the previous Sultan) from 1970 until 2020. In ${ }^{(2009)}$ Sultan Al-Harāşı̄ conducted a jurisprudential study; 'Haqeeqat Al-waqf wa Mashro'iyatuh'. In his paper he illustrated the opinions of $I b \bar{a} d \bar{l}^{-5}$ school (the privileged mathhab in Oman) which is almost close to Hanafi scholars' opinions on waqf. There are some studies which set out to determine the social rule of waqf in Oman for instance Muhammad Al-'isry (2009), Jamīl Al-Ghäfiry (2009) , Sultan AlHāshamī and 'Aydah Al-Nablāwy ${ }^{(2009)}$ while, Ahmed Al-Kindy ${ }^{(2009)} \mathrm{Mu}$ hammad Al-Hijry ${ }^{(2009)}$ and Abdu-Alwahāb al-Hayas ${ }^{(2009)}$ have focused their study on the educational waqf in Oman. A doctoral dissertation by Mãjid Al-Kindy (2015) about the 'Endowment foundation in Oman: an Islamic economic evaluation' reveals more information and illuminates the issues at stake about waqf in Oman. Three elements distinguish this from others:

1- It gives a critical interpretation of Omani waqf law.

2- It illustrates the Omani Fatwa institution's decisions pertaining to waqf.

3- It measures the investment performance of the Ministry of Endowment and Religious Affairs in the waqf fund.

Recently, a great effort has been made by Khälid Al-Rahby ${ }^{(2016)}$ in his study 'Endowment in Oman and its impact on cultural and social life from the $4^{\text {th }}$ to $12^{\text {th }}$ centuries A.H' and it took the waqf in Nizwa-ancient capital city of Oman- as a case study. Although the researcher struggled to collect these instruments from private libraries and waqf supervisors, he was able to reveal ancient waqf deeds.

\section{THE HISTORY OF THE WAQF INSTITUTION IN OMAN:}

The waqf institution in the Sultanate of Oman is one of the oldest waqf institutions in the Islamic world because Omanis accepted Islam in the

5 The Ibadi movement, Ibadism (Arabic: الإباضية, al-Ibādiyyah), is one of the Islamic schools of thought and one of the earliest mathab. Al-Ibadiyah is attributed its name to Abdullah bin Ibad al-Tamimi al-Basri, one of the leaders who fought with Ibn alZubayr and stood against the Umayyad dynasty. While the doctrine in its founding is attributed to al-Taabi Jabir bin Zaid al-Azdi. Ibadi are found in Oman and as minority in Algeria, Libya, Tunisia and in countries in East Africa. See for more details: (Muammar 1987). 
early age of Allah's final message even before the people of Mecca. The Companion Mazen Bin Ghadouba Al-Tai's entry into Oman in the sixth year of the Hijrah is an important event in Omani history. Upon his return from Madinah, he built the first mosque in Oman. Some researchers reported that he endowed several palms to his mosque in the city of $\mathrm{Sa}$ mail. Samail is still an agricultural area and retreat for the residents of the capital Muscat, especially in the summer (Al-Ghāfiry, 2009, p2/79-214; Al-Rahby, 2016). Furthermore, in the ninth year of the Hijrah, the two kings of Oman accepted Islam after they received a letter sent by the Prophet (紩) (see Figure 1). The people of Oman entered Islam voluntarily without dispute or combat. The Prophet approved the sovereignty of the two kings of Oman and sent a governor to Oman to represent the new Muslim state. The first governor was 'Amr bin Al-'Aāṣ. Oman remained in such a state until the leadership was assumed by the Umayyad state, which imposed full control over Oman. However, in $132 \mathrm{AH}$ at the end of the Umayyad state, the Omanis longed and achieved independence from Umayyads state and then from Abbasids state (Al-Sālimi, 1997,p36; Al-Siyābi, 2014, p1/111; Al-Bațashy, 2004, p1/25). The Ottomans state did not exercise control over Oman. This independent nation adopted the waqf system as the backbone of its socio-economic system.

One of the most important awqaf, waqf Al-Hugar, still exists today and it was established more than 1200 years ago. It was established by Alwarith bin Ka'ab Al-Kharosi, the ruler of Oman in the second century AH. He was a contemporary of Harun al-Rashid - the Abbasid State- from 197 AH / 798 AD. He established the waqf to those who supported him in securing the leadership of the nation so that he could establish justice and repel injustice to the people. This waqf is divided into forty shares as the number of people who supported him to secure his rule. It is still distributed to the offspring of those forty people (AlSiyābi, 2014, p2/24). 


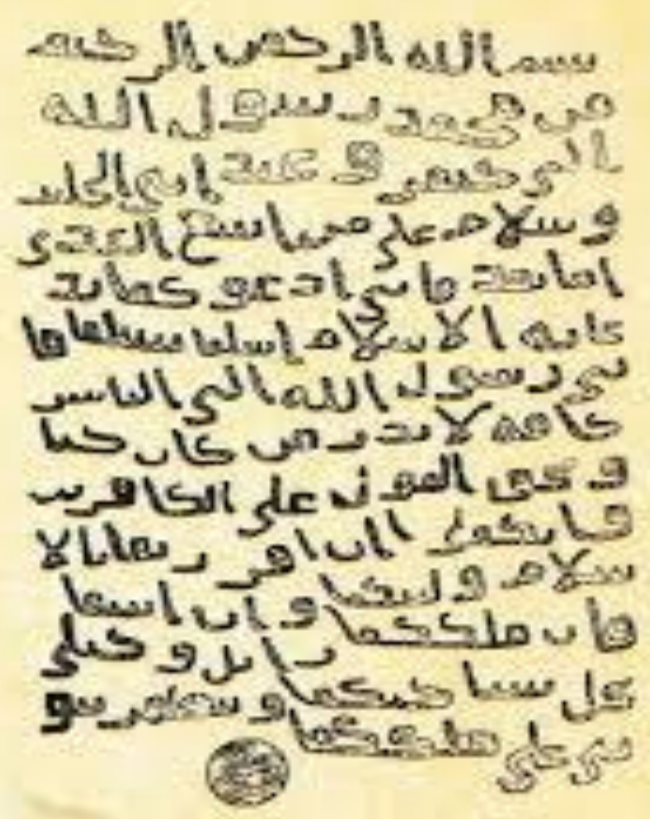

Figure 0 The Prophet Muhammad's letter to the two kings of Oman in 9 AHS. (Source: The National Records and Archives Authority in Oman)

History testifies that Omani waqf has flourished in Oman. It is said that Nizwa -the Ex capital of Oman- divided its wealth into three parts; onethird as a waqf, one-third to the treasury - Baitul mal -, and a third directly to the public (Al-Siyābi, 2014,p4/14). The Awqaf included all the people's needs small and large. There are endowments for the maintenance of warships and endowments for the manufacture of walking sticks for the blind, and endowments to feed the poor, and endowments to feed the birds of Mecca (Al-Busa'ìdī, 2002, p113). There has been great interest in the educational endowments. Many of the manuscripts were sponsored by the waqf of books and libraries. There are also awqaf for students, including the waqf of the great scholar Ibn Baraka -fourth century AH- for the students in his school. This waqf continues today and has been around for more than 1000 years. Another important educational waqf is that of the just ruler, Sultan bin Saif the second (1711AD-1719AD) for 
students (Al-Hijry, 2009, 2/63-93; Al-Kindi, 2009, 2/31-62). Awqaf flourished during the rule of the Ya'abirah family (1624-1741AD) (see figure 2). Many endowments in that era were dedicated to the maintenance of warships used to conquer the Portuguese and expel them from the Arabian Peninsula, India, and East Africa. They were also used to repel the aggression of the Persians toward Oman. It is worth mentioning that this fair ruler borrowed from the waqf funds the sum of 17,500 kilogrammes of silver to build the fortress of $\mathrm{Hazm}$, a military barracks (AlSālimi, 1997, p373). This is a clear indication of the richness of awqaf during that period.

In terms of its administration, the awqaf in the past was administered by the waqf founders who were trusted people. They were monitored by the inhabitants of the region and the beneficiaries. If they made mistakes, the matter would be raised to judge to hold the person accountable. If he was proven to be deceitful, then he would be removed from his position. In the commandments issued by the Omani rulers to their districts, there are some administrative directives regarding waqf. They called their governors to preserve the funds of the waqf and invest them. Among these commandments is the commandment of Nasser bin Murshid and 'Azzan bin Qays (Al-Sālimi, 1997, p514; Al-Busa'īdī, 2002, p103). 
8 Types of waqf in Oman

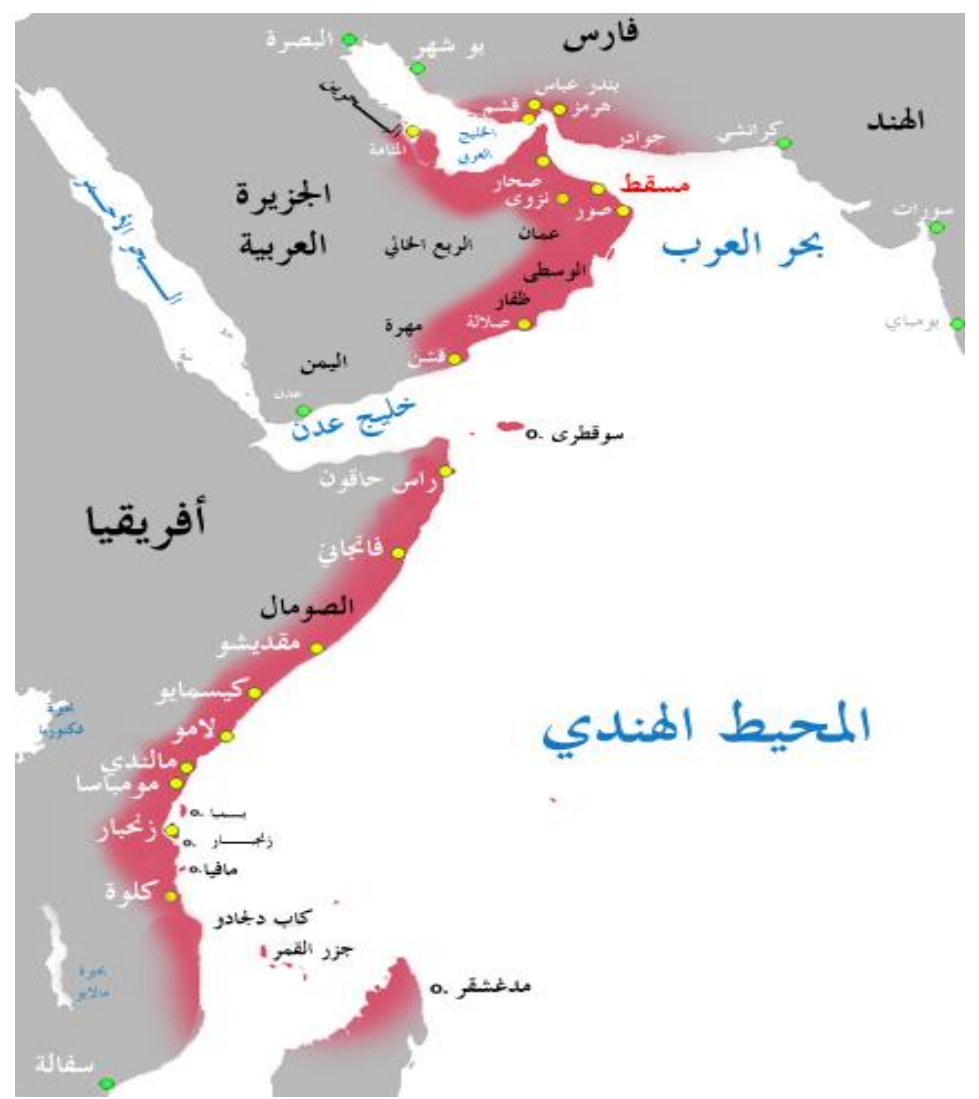

Figure 2The Omani Empire during the rule of the Ya'abirah family and early of Busa'idi family. (Source: www.academia.edu)

These endowments were administered in traditional ways without having a court dedicated especially to them until the modern era. There has since been a change in the methods of administering waqf.

\section{THE WAQF INSTITUTION IN THE SULTANATE OF OMAN IN THE MODERN PERIOD:}

With the development of life and the complexity of its obligations and the pivotal role that has been placed in the state in the care of the interests of its people, the Omani Waqf institution began to take another approach to the preservation of waqf and maximization of the economic returns. In the past the matter was determined by the waqf founder and his trustworthiness and care towards its development. This change in the 
preservation of waqf took place in the African section of the Omani Empire. In Zanzibar during the reign of Sultan Said bin Sultan (1856 AE) established a waqf committee that oversaw the waqf funds and distributed the salaries of the imams from the waqf. At the end of the nineteenth century $\mathrm{AD}$, the governing British occupation imposed the Indian law of endowments, which continued until the fall of the Omani government in 1963. The endowment was very prosperous in Zanzibar, which was considered the jewel of East Africa. The proportion of endowments in the capital city of Zanzibar, Stone City, was considered the fifth largest in the list conducted by UNESCO, which declared that this city is part of the world heritage and must be preserved. Among the most famous endowers was Mr. Hamoud bin Ahmed Al Busaidi (1870 AE), who built a mosque and a school for the study of the Quran and set up many properties to serve the mosque. This mosque is one of the richest mosques in Zanzibar due to the many endowments that supported it (see figures 3). Also, he built an endowment in Makkah dedicated to the poor of $I b \bar{a} d \bar{l}$ school from Zanzibar and Oman (Oberauer 2008; Khalfan 2014). With the present expansion of the Grand Mosque in Makkah, the supporting waqf properties were demolished, and Sultan Qaboos ordered the purchase of two other properties in Makkah at the cost of 31 million Omani riyals so that the waqf could continue playing its dynamic role (AlBusa'īdī, 2002, p104-105; Al-Kindy, 2015, p16-15) 
10 Types of waqf in Oman

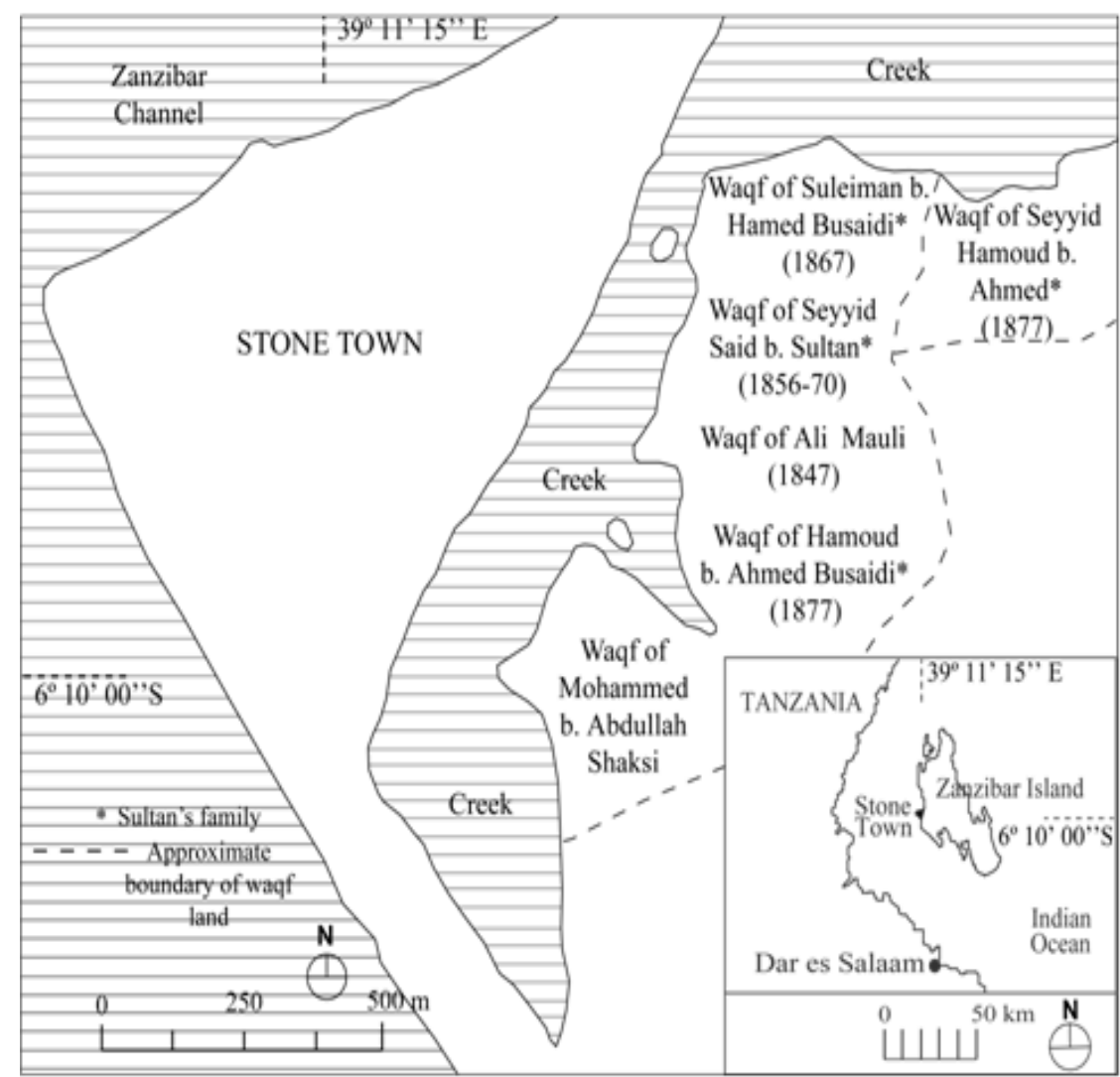

Figure 3 The 19th c. land of wqaf on the other side of the Stone City (source: Adopted from Myers (1993) and (Khalfan 2014).

Regarding the Asian segment of the Omani Empire, in 1926 AD, Imam Muhammad Abdullah Al-Khalili appointed Pasha Sulaiman Baro$n i$, who was originally from Libya and a member of the Senate and an envoy of the Ottoman Caliphate until its fall, to oversee the inventory and preservation of Awqaf and to hold in account its administrators. However, fate would have it that he would not manage to complete his mission ( Al-Kindy, 2015, p20).

In the early years of the reign of Sultan Sa'id ibn Taymur (1972 AE), in 1950 he established the Department of awqaf which was tasked with the inventory and documentation of endowments. This department is considered the first nucleus for the establishment of the Ministry of Endowments. 
In 1970, a special ministry was established for Awqaf and Bayt alMal. In 1973 it was changed to the Ministry of Awqaf and Islamic Affairs. It was then merged with the Ministry of Justice and became the Ministry of Justice, Awqaf and Islamic Affairs due to the 1982 Royal Decree (13/82). To further focus its administration, in 1997 the ministries were again separated to become the Ministry of Awqaf and Religious Affairs by virtue of Royal Decree (84/97).

There are two general directorates in this ministry nowadays. The first directorate is the General Directorate of Endowments and the Treasury, and the second is the General Directorate for the Development of Endowments and Treasury. The following outlines the organisational

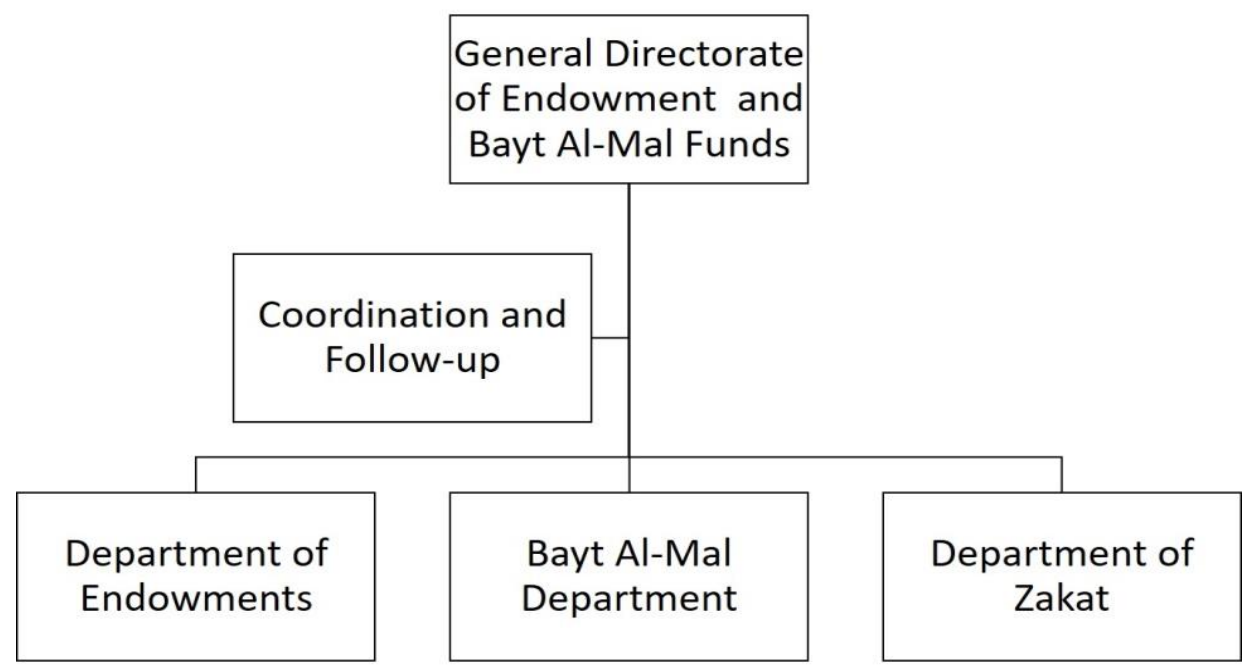

structure of these two departments (see figures 4 and 5 below).

Figure 4 Structure of General Directorate of Endowments and Bayt AlMal Fund. (source: https://www.mara.gov.om/structure.aspx?MID=27) 
12 Types of waqf in Oman

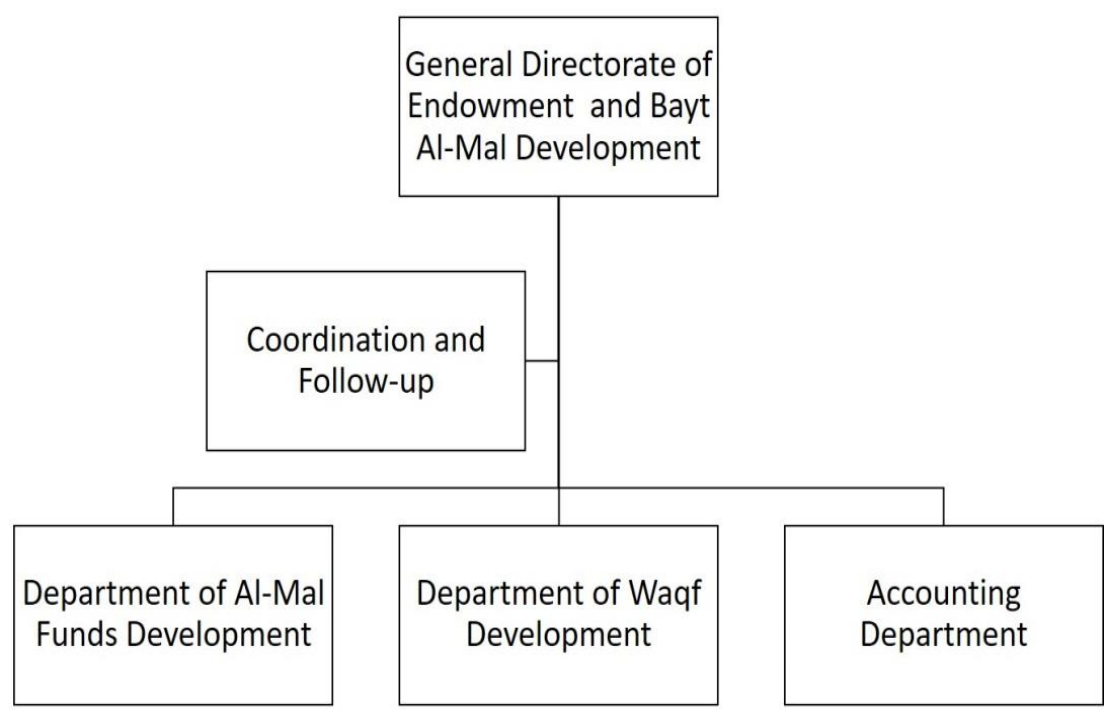

Figure 5 Structure of General Directorate for the Development of Endowments and Bayt Al-Mal Fund. (Source: https://www.mara.gov.om/structure.aspx?MID=27)

\section{THE UNIQUE FEATURES OF THE OMANI WAQF INSTITUTION:}

Omani endowments are dominated by orchards, fertile farms, and irrigation canals which are called Falaj (see Figure 6 below). The irrigation canals in Oman are watercourses which the Omanis use to irrigate their crops. The water sources are either groundwater from wells and springs or surface water from the valleys and rivers. These watercourses have a unique distribution system whereby each farm has a certain share of water. Currently, it is calculated in minutes or hours, while it was previously

${ }^{6}$ A falaj or 'aflaj'-plural- in Oman and Emiraties refers to water that runs through a channel dug in the earth. "The source of falaj water is groundwater found in the subsoil or valleys. The aflaj are divided into three main types: Dawoodi Falaj:These are long channels dug underground that run for several kilometres. Ghaili Falaj:These falaj receive their water from ponds or running water. Their depths do not exceed 3-4 metres. Ayni Falaj:These falaj draw their water directly from the springs (wells), including hot springs". 
calculated by the movement of the sun and the moon and the locations of the stars. These shares of the watercourses are owned by people. The waqf that contains the source of the watercourse is the best form of endowment since the water is leased in hour slots to irrigate farms and they require minimal maintenance. They are of great benefit at little cost (Al'isry, 2009, 2/-29; Al-Hijry, 2009, 2/63-93).

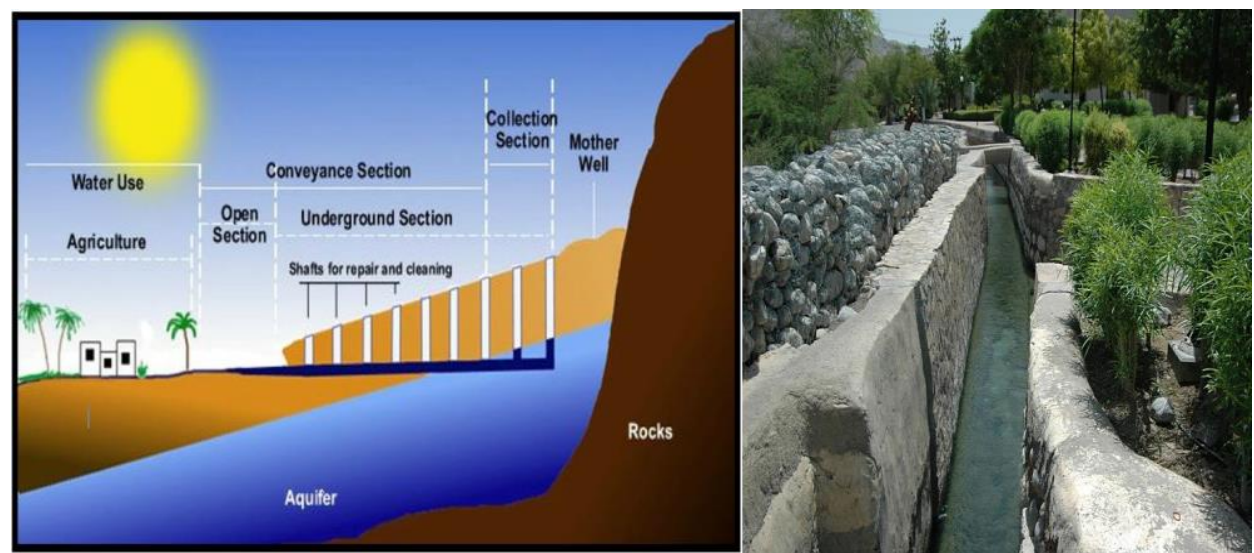

Figure 6 Falj System and Falj Dares in Nizwa city (source: ACSADUNESCO 1985)

Another unique feature of this prestigious institution is that it did not expand in the direction of endowments for the endower's children. Oman has the least of such types of the endowment in the Islamic world with most Omani scholars regarding it as impermissible. In the book of $A l$ Musannaf for Abu Bakr Al-Kindi Al-Omani: "Whoever endows his wealth to his inheritors, it is invalid as reported by our companions that the Prophet (能) said: (Allah has appointed for everyone who has a right what is due to him, and no bequest must be made to an heir) ${ }^{7}$, of this it is said: If this provision was set for them and those after them, then it is permissible as the poor then have a right to it, thus, inheritors can also use it but without selling it" (Al-Haraşy, 2009, p1/1-47). An early scholar was asked concerning a person who endowed his wealth to his inheritor, heir after heir; he said: The Omanis do not consider it permissible, except that it is given to an heir after which it is distributed to the poor. This re-

\footnotetext{
${ }^{7}$ Musnad Al-Rabi' bin Habib; Hadith 667; Sunan Abi Dawud 2870 Book 18, Hadith 9; Sunan an-Nasa'i 3641 Book 30, Hadith 31; Sunan Ibn Majah Book 22, Hadith 2817 and Jami at-Tirmidhi 2121 Book 30, Hadith 6,
} 
14 Types of waqf in Oman

striction on waqf is observed by both classical and contemporary scholars in Oman such as Shaykh Al-Sälimi (d. 1914) and Sheikh al-Khalili, the current Mufti of Oman (Al-Sālimi, 1993, p394; Al-khlīlī, 2004, p4/146) Another distinctive feature of waqf in Oman is that most of the lengthy jurisprudence books mentioned endowment under the chapter of bequeathing and were not awarded a separate chapter. It was also mentioned in the chapter of the endowment of mosques due to mosques being the prominent form of an endowment (Al-Harașy, 2009, p1/1-47).

Among the unique features of the Omani waqf institution is that it abolished some of the waqf that contradict the Shari'ah and the basic purposes of waqf, such as waqf of reading the Holy Qur'an over graves or placing lamps on graves. Sheikh Al-Sälimi issued a fatwa on the invalidity of such waqf because it is an illegitimate innovation. These endowments were ordered to be returned to their endowers, and if they are unknown, then to act in the general interests of the state (Al-Kindy, 2015, p19-20).

The Omani waqf has been characterised by great diversity. This diversity in the waqf is subject to the needs of the people. For example, at one time the waqf of vinegar for cooking meat was prevalent. This trend soon ended, yet the endowments kept their name although the endowments had since changed to serve different needs of the poor. Another endowment that ceased was milling to grind grain. There were many questions about this kind of endowment in Omani books of jurisprudence, however, it also disappeared due to changes in the needs of the people (Al-Rahby, 2016, p180).

\section{THE METHODOLOGY}

To study the nature of Omani waqf and to determine the types of waqf that are prevalent among Omanis, content analysis as a research method is used, especially conceptual analysis. It is a useful tool to determine the existence and frequency of concepts in a text. Therefore, it is necessary to select Omani waqf deeds, study them, analyse their contents and extract the founders' purpose of that waqf. To conduct this study, three stages were implemented. 
15 Said Rashid Said Al-Salmani, Ibrahim Nuhu Tahir

\section{STAGE ONE, THE SEARCH FOR WAQF DOCUMENTS:}

They are two sources of the data that is needed for this study. First; primary data in the form of waqf deeds, which were collected from different sources. Thirty waqf deeds from the Ministry of Awqaf and Religious Affairs were obtained, although contemporary waqf deeds could not be accessed. Most of those obtained are documents dating back to the $14^{\text {th }}$ century AH. 282 documents from the National Documents and Archives Authority ${ }^{8}$ were also used, all of which belong to the Omani Awqaf in East Africa when Zanzibar was the second capital of the Sultanate of Oman. Also, twenty documents were also found in the hands of Omani researchers such as Khalid Al-Rahbi and Hassn Al-Busaidi. These documents were hard to read and contained obscure words. Most of the documents pertained to the division of watercourses -Aflaj- in Oman. These sets of documents related to waqf form the core of this study. Second; secondary data that was collected from books and articles that showed interest in recording types of Omani waqf for example: (Al-Busa'īdī, 2002; AlKindy, 2014, 2015; Al-Raḥby, 2016; Al-'isry, 2009; Al-Hāshamī \& alnablāwy, 2009, 2/303-265; Al-Kindi, 2009, 2/31-62)

\section{PHASE TWO, MONITORING AND LIMITATION:}

During this phase, deeds documentations were read, and the relevant topics were extracted. More than two-thirds of the documents obtained in the first phase were bequests and contracts for sale, purchase and rent for the benefit of the waqf.

\section{THE THIRD STAGE, AN ANALYTICAL READING AND RESULT REPORTING:}

A great effort went into sorting out these documents and determining what types of waqf are. The writers analysed these documents and extracted their general characteristics while determining the types of waqf set-up by the Omanis. The result of this process is in the next section. Here are some of the findings that were obtained from the deeds:

\footnotetext{
${ }^{8}$ It is a set of documents had chosen by National Records and Archives Authority of the Sultanate of Oman from among the thousands of documents. These deeds were issued in two volumes. See (Quri'sa et al. 2014)
} 
16 Types of waqf in Oman

1. Most of the old documents are written by Aflaj supervisors since the waqf in the past either watered farms using Aflaj water or a certain percentage of those Aflaj (for example see figure 7).

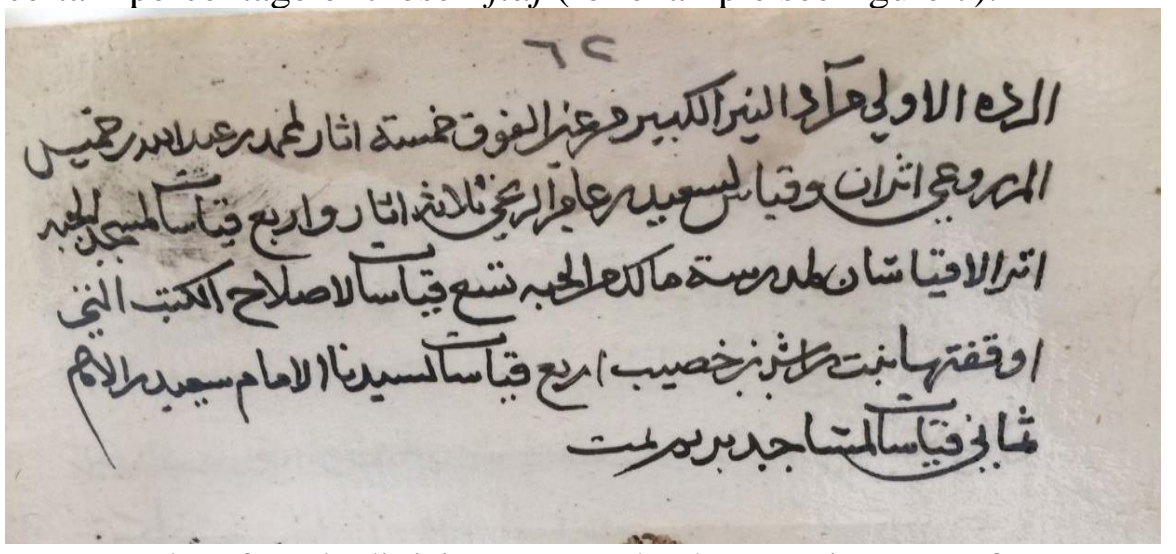

Figure 7 Example of Falj division water deeds contain a waqf water share. (Source: a copy collected from Khalid Al-Rahbi)

2. All waqf documents were written in an easy language, indicating the knowledge of the authors of these documents of the rules of the Arabic language.

3. Most of these documents were written in clear handwriting except for some incredibly old documents, some of which were omitted. These were referred to manuscript experts for deciphering.

4. Waqf to Mosques is the most common type of endowment in Oman.

5. The waqf of the shops concentrated in the capital Muscat, while the rest of the areas of Oman consisted of waqf of farms and Aflaj.

6. Some endowments included the identification of money used at that time.

7. These endowments also showed some of the administrative and social figures in the society to which people refer in matters of restricting their documents and contracts, such as the names of some judges and heads of the Awqaf department and its employees as well as some knowledgeable figures.

8. Non-Omanis had a prominent role in establishing endowments in Oman.

9. Some documents are originally bequeaths containing waqf. 
10. Some documents are very old but were verified later by the regional governor. It is as if the endower wanted to ratify and document with the authorities so that it would not be changed after him.

11. Waqf documents have been attached to a collection of documents of contracts of sale and purchase of the past, such as Waqf documents of the Shujaiya Mosque in the Mutrah city.

12. Some documents contain a series of sales and purchasing transactions on the same page. For example, when Hajj Ali Musa Khan Al-Baluchi endowed his mosque, known in his name, in Muscat city, this document started with a red line in 1330 AH: written by Sultan Faisal bin Turki to the judge in his time Saleh bin Amer Al-Tewani. In the same year, Ali Bin Musa bought the commercial shop from Sharifa bint Mohammed, and the writer of the contract is Judge Saleh Amer Al-Tiwani. In 1339 AH Musa Ali endowed the shop for his mosque and the writer of the contract is the son of the former judge, Muhammad Saleh Al-Tewani.

13. The role of just scribes in the formulation of the legal instruments of the waqf is clear. It is characterised by clarity and strength of phrase.

14. All the old documents were written in black except for documents that had a comment to some Sultans which was written in red. The newer the document, the more it was written in blue with precise writing. This is evidence of the use of modern pens in the $14^{\text {th }}$ century AH.

15. Waqf for children dominated the Awqaf of Omanis in the Sultanate of Zanzibar during the days of Omani rule. This was unlike the endowments in Oman, where the jurists placed many restrictions on it. This is due to the mixing of Omanis in Zanzibar where multiple doctrines influenced the jurisprudence of scholars. By ending this stage, which is the backbone of this article and its main pillar, we move on restricting the types of endowments.

\section{THE TYPES OF ENDOWMENTS IN OMAN}

The main result of this study is that Waqf in Oman vary widely due to differences in people's needs and living conditions. This is an indication of the importance of waqf in the lives of Muslims economically, socially and also in terms of security. Some researchers counted that the purposes of the Omani endowers exceeded 48 (Al-Busa' $\bar{l} d \bar{l}, 2002$, p108) whereas 
18 Types of waqf in Oman

the writer regards them as sixty. In the diversity of these endowments is evidence that they played a prominent role in the economic and social development of the country, as they seek to satisfy the needs of the people.

The following is a list of the types of waqf in Oman:

1. Endowments for mosques: all endowments for the maintenance of mosques and all its needs such as furniture, lighting, restoration, etc. There are also special awqaf for wells, its rope, and buckets.

2. Aflaj Endowments: these watercourses have awqaf dedicated to their maintenance and preservation so that they can continue to perform their full functions. These watercourses are the lifeblood of the former Omani villages and cities. It is the water they use to eat, drink and use for their personal uses, as well as to irrigate.

3. Endowments of schools of the Holy Quran: for maintenance and construction, as well as for the accommodation of teachers.

4. Teacher endowments: it is currently spent on teachers of the Holy Quran, where they are paid a monthly salary from the Ministry of Awqaf.

5. Student endowments: It is an endowment for the students of the Holy Quran and the Islamic sciences, where they are given money to encourage them to study.

6. Endowments for reading the Holy Quran: to read the Holy Quran on certain days such as the days of solace or in the eighth day of the month of Thu'l-Hijjah or alternatively Zulhijja which is the twelfth and final month of the Islamic calendar. One of the great scholars of Oman Sheikh Al-Sälimi abolished the waqf for reading the Holy Qur'an on graves and considered such a practice invalid.

7. Endowments for books: either by assigning a collection of books to students or to spend the waqf on copies of books and binders and restoration.

8. Endowment for the purchase of paper: this is used to purchase paper, ink and writing instruments for recording Shari'ah provisions. 
19 Said Rashid Said Al-Salmani, Ibrahim Nuhu Tahir

9. Endowment for orphans: it is either in general or an endowment for a person's child.

10. Endowment for beggars: it is general for the poor and needy who ask people in the markets or at specific times.

11. Endowment for the blind: it is used for the blind who need help.

12. Endowment for walking sticks for the blind.

13. Endowment for lepers: this is for those who suffer from leprosy. Currently, this waqf goes to the Ministry of Social Development.

14. Endowment for medicines for children and the poor.

15. Endowment for the sick.

16. Endowment for lamps: this is used for the lamps of the mosque before the presence of electricity.

17. Endowment of bucket and ropes for wells.

18. Endowment for the worshipers in Oman: this waqf is spent on worshipers in a particular mosque to encourage praying in congregation.

19. Endowment for the worshipers in the Grand Mosque in Makkah.

20. Endowment for ending the fasting of the fasting persons in Ramadan by providing food to break the fast in the mosques.

21. Endowment for fasting it is the payment of certain amounts to those who fast in a certain month, and it includes all people.

22. Endowment for fasting for the six days of Shawwaal by providing food to break the fast in the mosques.

23. Endowment for fasting Monday and Thursday by providing food to break the fast in the mosques.

24. Endowment for Suhoor - it is a meal supposed to be eaten before sunrise in the month of Ramadan- which is special for the poor.

25. Endowment for the ninth of Thu'l-Hijjah to be spent as charity to the poor.

26. Endowment for lunch for a particular mosque.

27. Endowment for serving breakfast for a particular mosque after Fajr prayer.

28. Endowment as expiation-kafärah-for the endower.

29. Endowment for the poor of a certain village.

30. Endowment for a certain village, and it includes all the people of that village including their poor and rich. 
20 Types of waqf in Oman

31. Endowment for young adults, which is an incentive for them to serve the community.

32. Endowment for a certain tribe.

33. Endowment for buying coffins.

34. Endowment for cemeteries: to prepare tombs and cemeteries.

35. Endowment for the Houses of cleaning the body of the deceases and those involved in related tasks.

36. Endowment for digging graves given to those who dig graves.

37. Endowment to visit the graves: this is where the endower dedicates it to those visiting his grave after his death.

38. Endowment of public baths dedicated specifically to women and others to men.

39. Endowment of birds for their food, and the birds of The Holy City Makkah. There is a document from the seventh century $\mathrm{AH}$, mentioning such a waqf, although Sheikh Al-Sälimi (1914 EH) annulled such a waqf as it leads to harm in the form of the accumulation of birds inside the Great Mosque that desecrate its sanctity.

40. Endowment of vinegar: it seems that the Omanis once used vinegar in a lot of their food.

41. Endowment for barbeque ovens or pits: this is a special place to roast the meat on special occasions and holidays. All villages in Oman have such a pit for public use.

42. Endowment for roads: this is used for the maintenance and construction of roads.

43. Endowment for cooking utensils: it is an endowment to buy large pots for cooking in public events.

44. Endowment for fences: this is considered a security endowment, many of the cities of Oman have surrounding walls. The endowment is to maintain these fences and defensive fortifications.

45. Endowment for steel: it refers to the machine used to make Omani bread.

46. Endowment of flour mill.

47. Endowment of mortar to grain grains.

48. Endowment for kerosene: it is used to light lamps and candles used in mosques and public areas.

49. Endowment for wells: it is used to access water for domestic use and for the maintenance and construction of wells. 
21 Said Rashid Said Al-Salmani, Ibrahim Nuhu Tahir

50. Endowments for accidents: it is used to aid those who must pay blood money for manslaughter or calamities that afflict a village and require material aid.

51. Endowments for markets: it is used to repair markets for the people of a particular town.

52. Endowments for public halls used for public events, weddings and condolences.

53. Endowment for hospitality: it is used to host guests visiting a certain village.

54. Endowment for the Omani House of Ribat: It is a house for Omani poor pilgrims in Makkah.

55. Endowment for warships: it is used for their maintenance during the reign of the Ya'abirah family who ruled Oman between 1624-1741 AD and the beginning of the rule of the Busa' $\bar{\imath} d \bar{\imath}$ family -from $1741 \mathrm{AD}$ to the present era- where the Omani navy fought fierce battles against the Portuguese and the Persians.

56. Endowment for buying arms, bullets and sulphur for defensive purposes.

57. Endowment for sugar cane presses: this is used now in for the poor.

58. Endowment for watering the animals coming and going from Omani cities.

59. Endowment for bread which is distributed to certain mosques.

60. Endowment for sweets: It is intended to bring joy to the hearts of the poor.

61. Endowment of the Qarat tree where its fruits are used to treat leather.

Despite our efforts to inventory Waqf's types in Oman, it is possible that the information may prove to be incomplete. However, other researchers can work on completing this task.

\section{CONCLUSION}

This study is aimed at reviving the practice of waqf by addressing the purposes and areas of endowment in Oman. It comes in the context of international interest in the institution of waqf. This ancient institution has a proven economic and social existence. This study focused on two main objectives. The first is defining the waqf institution in Oman and 
22 Types of waqf in Oman

studying its historical development. The second is to study the conditions of the endowers in terms of their purpose and goal of that waqf.

This article is dedicated to Omani waqf and examining the objective of endowers in establishing the waqf. The writer concluded that the Omani waqf preserved those features that were present in the waqfs of the Sahabah by not including many conditions and not advocating family waqf. The conditions of the endowers were simple conditions and easy to understand and implement. The majority of Oman awqaf were dedicated to mosques and teaching the Holy Quran, and all remaining waqf dealt with social affairs.

The writer makes the following recommendations.

1. Preserving the waqf system and its systems by not rushing to adopt new criteria for the development of the waqf system, only after confirming it is in line with the foundations on which the waqf system was built and preserved for many centuries.

2. The conditions of endowers are part of the Islamic cultural heritage that should be preserved. They are economic indications of the great role played by ordinary individuals in supporting the economy and preserving society.

3. People should be enlightened about the importance of waqf and the revival of this practice. People should be encouraged to donate general endowments that are easy to manage and maximize their return, and not to restrict waqf to conditions that affect them in the future.

5. Encouraging people to donate to charity, and to minimize family waqf due to the many problems associated with this type of endowment.

6. Endowers should continue to address the needs of people in our time. The areas of waqf are not limited. It is possible to endow for the establishment of handicrafts, training centers, economic studies of the needs of the Muslim community, scientific research, establishment of industrial institutions and other factors that can benefit society and reduce the burden on the state budget. 
23 Said Rashid Said Al-Salmani, Ibrahim Nuhu Tahir

7. Waqf documents should be preserved and waqf agents should be asked to make copies of documents for fear of damage or loss.

However, given the importance and age of this institution, it needs further investigation to show its advantages and roles and deserves more researchers in the future study.

\section{References}

Al-'isry, Muhammad. 2009. “Al-Waqf Fi Muf'radāt Al-Tārikh AllIj'timā'ī.” In Al-Waqf Fi Oman, 2/1-29. Muscat, Oman: Omani Studies Center.

Al-Aghbiry, Said Ahmed. 1993. "Tajrubat Oman Fi Idārt Al-Awqāf.” In Naḥu Dawr Tanmawī Llwaqf, edited by Markaz Abhāath Al-Waqf wa Ad'dirāsātAl-Iqtișādyh, 197-209. Kuwait: Ministry of Endowment and Islamic Affairs Kiwait.

Al-Asqalani, Ibn Hajar. 1995. Al-Ișābh F̄̄ Tmyyz Asşhāâhh. 1st ed. Beirut: Dār Al-kutub al-'ilmi'yah.

Al-Bațashy, Saif. 2004. Ithāa Al-A'yān Fi Tārik Ba'ḍu 'ulamā Oman. 2nd ed. Muscat, Oman: Office of the Special Adviser to His Majesty the Sultan for Religious and historical Affairs.

Al-Busa'īdī, Musā. 2002. Ashk'şiyh Al-i'bā'yh Llwaqf Fi Sultanate of Oman. 1st ed. Muscat, Oman: Ministry of Endowment and Religious Affairs.

Al-Ghāfiry, Jamīl. 2009. “Al-Awqāf Wa Al-Amn Al-Ij’timā'1̄.” In AlWaqf Fi Oman, edited by Omani studies center, 2/179-214. Muscat, Oman: Omani Studied Center, Sultan Qaboos University.

Al-Ḥarașy, Sultān. 2009. "Haqeeqat Al-Waqf Wa Mashro'iyatuh.” In AlWaqf Fi Oman, edited by Omani Studies Center, 1/5-47. Muscat, Oman: Omani Studied Center, Sultan Qaboos University.

Al-Hāshamī, Sultan, and 'aydaḥ al-nablāwy. 2009. "Al-Waqf L-Khyry Wa Dawruhu Al-Ijtimā'ì.” In Al-Waqf Fi Oman, 2/265-303.

Al-Hijry, Muhammad. 2009. "Al-Athar Al-'ilmī Llwaqf; Bidīy as Case Study." In Al-Waqf Fi Oman, edited by Omani Studies center, 6394. Muscat, Oman: Omani Studied Center, Sultan Qaboos University.

Al-Jaḥāfi, Salim. 2004. “Al-Ather Al-Ḥaḍary Llwaqf Fi Sultanate of Oman." Zaytōnah university.

Al-khlīlī, Ahmed. 2004. Al-Fatawa. 2nd ed. Muscat, Oman: Maktabt alajyāl. 
24 Types of waqf in Oman

Al-Kindi, Aḥmed. 2009. "Al-Waqf Ata'līlmī Fi Oman Wa Athruhu Alā Al-Harakh Al-Līlmiyh.” In Al-Waqf Fi Oman, edited by Omani studies Center, 31-61. Muscat, Oman: Omani Studied Center, Sultan Qaboos University.

Al-Kindy, Mājid. 2014. "Al-Ḥimāyah Al-Madaniyh Lialwaqf Fi Attashri'aāt Al-Omaniyh.” ALEDARI 139: 95-120.

_. 2015. "Endowment Foundation in Oman; An Islamic Economic Evaluation." Yarmouk.

Al-Raḥby, Kālid. 2016. "Al-Waqf Fi Oman Wathruhu Fi Al-Hyat AlThaqafiyh Wa Al-Ig'tima'iyh; Priod from 4-12 A.m; Nizwa City as Case Study." Sultan Qaboos University.

Al-Sālimi, Abdullah. 1997. Tuhfat Al-A'yān. Muscat, Oman: Maktabt AlIstiqāmah.

Al-Siyābi, Salam. 2014. Oman 'abra Al-Tārikh. 2nd ed. Muscat, Oman: Ministry of Heritage and Culture.

Al-Zarqā, Muștafá. 1989. Sharh Al-Qawā'id Al-Fiqhīyah. Edited by 'Abd-As'satār Abū-Judahd. 2. 2nd ed. Damascus: Dar Al-Qalam.

Alḥayas, Abdu-Alwaḥāb. 2009. Al-Waqf Al-Ilm̄̄ Wa Istithmāruhu. Omani Stud. Muscat, Oman: Omani Studied Center, Sultan Qaboos University.

Çizakca, MURAT. 1998. "AWQAF IN HISTORY AND ITS IMPLICATIONS FOR MODERN ISLAMIC ECONOMIES *." Islamic Economic Studies 6 (1): 43-70.

group of authors. 2012. Pasha Sulaiman Baroni. Edited by center of Omani studies. 1st ed. Muscat, Oman: Sultan Qaboos University.

Ibn Al-Athir. 1994. Usad Al Ghabah Fi Ma'rifat Al Sahabah. 1st ed. Beirut: Dar al-Kutab.

Khalfan, Khalfan Amour. 2014. "Waqf as a Model for Production and Conservation of Architectural Heritage." Global Journal of HUMAN-SOCIAL SCIENCE: D History Archaeology \& Anthropology 14 (3): 9.

Kuran, Timur. 2001. "The Provision of Public Goods under Islamic Law : Origins , Impact , and Limitations of the Waqf System." Law \& Society Review, 35 (4): 841-98.

- 2013. "The Political Consequences of Islam's Economic Legacy." Philosophy \& Social Criticism 39 (4-5): 395-405. https://doi.org/10.1177/0191453713477350.

Mohsin, Magda Ismail Abdel. 2010. "Revitalization of Waqf Administration \& Family Waqf Law." US-China Law Review, ISSN 
1548-6605, USA 7, No.6: 57-64.

Muammar, Ali Yahya. 1987. Ibadi among Islamic Sects.. Algeria: . Edited by The Arab Press. aljeria.

Mușabh, Mu'taz Muhammad. 2013. "The Role Of Charitable Endowment In Economic Development." Islamic Univercity of Gaza.

Myers, Garth Andrew. 1993. "Reconstructing Ng'ambo: Town Planning and Development on the Other Side of Zanzibar." University of California, Los Angeles.

Oberauer, Norbert. 2008. "Fantastic Charities': The Transformation of Waqf Practice in Colonial Zanzibar." Islamic Law and Society 15 (3): 315-70. https://doi.org/10.1163/156851908X366156.

Omercic, Jasmin. 2016. "Waqf in Bosnia and Herzgovina: Potencial Socio-Economic Role in Light of Islamic Economic." International Islamic University Malaysia.

Quri'sa, Khaldoun, Al-mi'zurī Al-arusī, Farhat Alja'bīrī, and Farhat ADrīsī. 2014. The Historical Relations between Oman and East Africa between the Years 1882-1938. Edited by Wafīq Kīlinī. 1st ed. Muscat, Oman: The National Documents and Archives. 